\title{
Sustainable Campus Income Generation Initiative and Social Entrepreneurship at a Public University
}

\author{
Rugayah Hashim 1, Mohd Shazali Md Sharif 2, Rosmaliza Muhammad 2, Zaidi Mohd Aminuddin ${ }^{3}$ \\ ${ }^{1}$ Research \& Innovation Division, \\ 2 Faculty of Hotel \& Tourism Management, \\ ${ }^{3}$ Faculty of Business \& Management, \\ Universiti Teknologi MARA, Selangor Branch, Malaysia
}

guy73106@yahoo.com, shazalisharif@gmail.com, rosmaliza07@gmail.com, pmzaidi@yahoo.com.my 013385228:

\begin{abstract}
Campuses with substantial acreage have the advantage of biodiversity, populace, and facilities that would allow the initiation of multi projects for income generation and sustainability. For Universiti Teknologi MARA Cawangan Selangor (UCS), the fish pekasam project originated from the natural resources available on campus, which are the twelve lakes inhabited with tilapias and other fishes. Elements of social entrepreneurship from the sale of the pekasam (fermented) fish allowed for income generation to the campus. Aside from that, direct training was given to the students and staff who participated in the project. The initiative helped increase the campus's happiness index.
\end{abstract}

Keywords: sustainable campus; narrative research; social entrepreneurship; fish pekasam

eISSN: 2398-4287 @ 2020. The Authors. Published for AMER ABRA cE-Bs by e-International Publishing House, Ltd., UK. This is an open access article under the CC BYNC-ND license (http://creativecommons.org/licenses/by-nc-nd/4.0/). Peer-review under responsibility of AMER (Association of Malaysian Environment-Behaviour Researchers), ABRA (Association of Behavioural Researchers on Asians) and cE-Bs (Centre for Environment-Behaviour Studies), Faculty of Architecture, Planning \& Surveying, Universiti Teknologi MARA, Malaysia.

DOI: https://doi.org/10.21834/e-bpj.v5i13.1948

\subsection{Introduction}

Campuses with substantial acreage have the advantage of biodiversity, populace, and facilities that would allow the initiation of multi projects for income generation and sustainability. Initiating activities and projects that leverage the campus facilities and workforce can lead to sustainability and wellbeing among the populace. Therefore, the paper narrates the double-phase events involved in the change process aimed at embedding concepts of sustainable income generation through social entrepreneurship by engaging the university students and staff. In the case of Universiti Teknologi MARA, Selangor Branch (UCS), the income generation initiative was through leveraging one of twelve lakes on campus. All the lakes have tilapias and other indigenous fishes. For this particular activity, the lake at Alam Bina section was the focus as the tilapias have grown to maturity. Realizing the opportunities available for generating income, four departments joined forces to net the fishes and convert them into a local, fermented side dish known as pekasam fish. Prior research on the viability of the project indicated positive outcomes and impacts. For the first phase, fifty-seven students from the culinary program of the Faculty of Hotel, Tourism Management (FPHP) were given exposure on how to scale and clean live fishes harvested by the staff from the Facilities and Campus Police departments. Three lecturers from FPHP instructed the students on how to properly cleanse the fishes in readiness for the pekasam fish fermentation process. The second phase was the post-project activity was the sales, marketing, and promotion elements. The students were mentored on these elements by promoting the pekasam fish product through any mode or channel. Any orders were fulfilled, and hand-delivered as all of the purchases were through cash exchanges.

eISSN: 2398-4287 @ 2020. The Authors. Published for AMER ABRA cE-Bs by e-International Publishing House, Ltd., UK. This is an open access article under the CC BYNC-ND license (http://creativecommons.org/licenses/by-nc-nd/4.0/). Peer-review under responsibility of AMER (Association of Malaysian Environment-Behaviour Researchers), ABRA (Association of Behavioural Researchers on Asians) and cE-Bs (Centre for Environment-Behaviour Studies), Faculty of Architecture, Planning \& Surveying, Universiti Teknologi MARA, Malaysia.

DOI: https://doi.org/10.21834/e-bpj.v5i13.1948 


\subsection{Literature Review}

\subsection{Explaining 'Pekasam Fish' and the Makings of 'Pekasam Fish'}

Pekasam is a Malay traditional food preservation through fermentation technique that is well-known and is still practiced in Malaysia. Pekasam is a traditional method that aims at maintaining the durability of fresh foods such as fish, chicken, meat, and other game by using salt, acid, or vinegar so that the food product can last longer (Mahyudin, Ibadullah, \& Saadin, 2015). Newly caught fish do not last long if it is not stored in the freezer. When there is no freezer, the most common way to retain the fish's freshness is to clean and apply the fish with salt and asam slices as soon as possible. Another method used in the past to ensure fish and other perishables last longer is through smoking. A famous example is the smoked salmon.

Ikan pekasam is fresh fish that has undergone several processes before being left to ferment within a specific period. The technique of fermentation has been passed down from one family to another. The aim of preserving fish and meat was for food security at that time when there was no modern equipment such as the refrigerator for keeping fresh food. Much like other cultures in the world, food preservation has become a popular method leading to well-known delicacies associated with the country; for instance, kimchi is to Korea. Anyhow, pekasam fish is very popular in the northern states and the east coast of Peninsular Malaysia. The state of Perak is also well-known for its freshwater fishery, especially after the construction of the Chenderoh Lake Dam. The dam has become a hub for the breeding and supply of freshwater fish meant for the production of pekasam. Sir Richard Olof Winstedt also mentioned the fish pekasam in Perak in his book, The Circumstances of Malay Life (in Ilham, Zaihan, Hakimi, Ibrahim, and Shahrul (2020).

To continue, salt and asam slices are the main ingredients used for producing pekasam fish, which also act to maintain the freshness of the fish's flesh (Mahyudin et al., 2015). The salt and asam slices will also make the pekasam fish ferment so fast that even the bones can be eaten. The last process of making the pekasam fish is the use of toasted, grounded rice. Fish pekasam has been known to last for years, even if they are not placed in the refrigerator (ibid).

\subsection{The Ingredients for Pekasam Fish}

\subsubsection{Fish}

Common practices of producing pekasam fish are by using freshwater fish. The first step is that the fish must be thoroughly scaled and cleaned. Make sure that all of the fish's internal organs are removed and cleaned. This is to ensure that the fish will be well preserved during the fermenting period. The freshwater fish is commonly caught from rivers, water catchments, canals and, paddy fields. Commercial producers of pekasam fish prefer to breed the fishes in their ponds in order to control and main the supply. The types of freshwater fish that are commonly used in producing pekasam fish are the tinfoil barb (lampam), tiny scale barb (loma), tilapia, climbing perch (puyu) dan snakehead (haruan).

\subsubsection{Salt}

In producing pekasam fish, simple, clean coarse salt is the most common sodium chloride preferred by the producer. The ratio of salt usage is recommended at one kilogram of fish to one hundred grams of salt. In other words, the ratio of salt usage is ten percent of the total fish weight after the cleaning process. The use of salt in making pekasam fish is crucial in the fermentation substrate, as stated by Mahyudin et al. (2015) and Muryany et al. (2018), fermented food, especially from fish or seafood requires lactic acid bacteria such as Lactobacillus strains to aid the fermentation process.

\subsubsection{Rice}

The last ingredient in the pekasam fish fermentation process is the coating of toasted rice. After the three-day fermentation of fish slathered with coarse salt, the last part requires the use of ground, toasted rice. As noted by Mahyudin et al. (2015), the coarsely ground, toasted rice will aid the fermentation substrate. The amount of rice used should be adjusted according to the quantity of fish and salt. The ratio of rice is also ten percent of the total fish weight after been cleaned. The function of the rice in the fish pekasam production is to absorb the moisture from the liquid emitted from the dehydration process and to enhance the taste of the pekasam fish when fried.

\subsubsection{Asam Gelugur (Garcinia atroviridis) Slices}

Slices of asam gelugur or garcinia atroviridis are part of the main ingredient in the production of pekasam fish, where its function is to provide a tangy taste to the fish. Indirectly, the asam slices also act as a natural preservative that allows a longer shelf life for the pekasam fish (Zaman, Lin, \& Phing, 2018). Studies have found that asam slices are better than tamarind paste as it can be removed at any time. The use of an acidic ingredient is important to the taste of the pekasam because of the acid-assisted fermentation process (Ezzat, Zare, Karim, \& Ghazali, 2015).

\subsection{Campus Sustainability}

Over the past two decades, public universities in Malaysia have started to generate income through various means. Strategies for income generation were through the commercialization of research and innovation of products and services. The dynamics of university organizational change were significantly observed on-campus environmental sustainability as posited by Mcmillin and Dyball (2009) and Brinkhurst (2011). Being self-sustainable is an important move for public institutions of higher learning as they will be independent of government financial assistance. However, this move may take time for public universities, but having a certain percentage of independence shows that the theories taught are being applied to real-life cases. Moreover, if campuses have natural and biodiversity 
resources, the greatest potential for long-term change comes from active intrapreneurship by faculty and staff (Brinkhurst, 2011). For Universiti Teknologi MARA Cawangan Selangor (UCS), the 1,000 campus acreage is naturally bestowed with lush greenery and 12 lakes. Good ties with the Fishery Department of Selangor and Pahang have seen several exchanges of goodwill in the form of fish fries given to the UCS for tracking hybrid fish growth. Over the years, UCS has received more than 70,000 fish fries from two species; tilapia and the hybrid tinfoil-lemon fin barb (ikan lampam-kerai). The latter is an expensive breed of freshwater fish, but the former is popular among locals. Banking on these campus resources, the idea for making fish pekasam was the practical entrepreneurship approach. Furthermore, with a significant number of students to staff population, the campus sustainability project will provide the platform for multiple relationships toward collegiality, hence improving the university's happiness index. Also, UCS is home to the Faculty of Hotel and Tourism Management (FPHP). One program offered by FPHP is culinary of local and traditional dishes. Students from this program were part of the campus sustainability activity as the exposure to scaling and cleaning freshly-caught live fishes would be beneficial to them. Brinkhurst (2011) said it well that campus staff and students should be encouraged for further innovation towards campus sustainability and 'intrapreneurship.' In doing so, the activity will overcome barriers between staff and students, yet realizing their potential as leaders of change (ibid). To quote Brinkhurst (2011), "faculty and staff are the most important and yet unrecognized champions of campus sustainability. Supporting their efforts is an essential part of achieving lasting progress towards sustainable universities".

Reviews on-campus sustainability literature on the Web of Science online database resulted in 657 hits over the past five years. The extensive articles on universities undertaking campus sustainability initiatives meant that UCS is on the right track for income generation. The double-pronged initiatives also showed that the campus populace can mutually agree on an interest that can benefit the members of the activity yet provide a source for social entrepreneurship.

\subsection{Social entrepreneurship explained}

Social entrepreneurship has been embedded in most profit-based transactions, including barter trade. However, the meaning and theoretical implications were only justified in recent years. Social entrepreneurship is described as a nascent field that has proliferated and has gained increased attention from many sectors (Martin \& Osberg, 2007). Social entrepreneurship has become standard on university campuses (ibid) as the impact of it encompasses social change, potential payoff, and last, transformational benefit to society (ibid). The fish pekasam project by Universiti Teknologi MARA Cawangan Selangor (UCS) fulfills the criteria for social entrepreneurship and the impacts on the community.

As explained by Martin and Osberg (2007), the word "entrepreneurship" connotes a unique, innate ability to sense and act on an opportunity with a unique determination to create and bring about something new to the world. Social entrepreneurship is alertness to opportunity for value creation (ibid). Entrepreneurship undertakings should not be limited to university graduates but should be practiced with the current student intake (Daub, Hasler, Verkuil, \& Milow, 2020). With that elucidated, UCS should have more similar events for holistic impacts on those involved.

\subsection{Methodology}

The methodology is divided into two parts; the first method is the processes involved in the pekasam fish production, and the second part is the narrative research design used for the project.

\subsection{Two-phase pekasam fish production}

The hands-on pekasam production required two phases; for the first phase, tilapia fishes were harvested from the lake. Fifty staff and students took part in the netting of the fish. The final weight of the fish netted was 150 kilograms. The live fishes were immediately scaled and cleansed by the students from the Culinary Program of the Faculty of Hotel and Tourism Management. Four cleansing processes were undertaken using calamansi limes, and the remaining two processes used flour. Running water is vital during the cleansing process because of hygiene factors and, most importantly, to eliminate fish odors.

Immediately after the 150 kilograms of fish were adequately cleaned, they were rubbed with coarse organic salt and nicely stacked in buckets. These buckets must have the lids put on tightly to avoid contamination. Each bucket consisted of approximately 23 kilograms of fish. These buckets were then stored in the chill room for a week to ten days. After the fermentation period, the fishes were taken out, and any liquid in the bucket was poured out. Once done, the fishes are rubbed with a thick layer of roasted rice that has been coarsely grounded. Once the bucket is almost filled, pieces of asam slices are scattered on top, and the lid is once again closed tightly. This second phase of fermentation requires approximately two weeks. Once the period is over, the "fish pekasam" is considered mature and ready to be vacuum sealed and sold. Each pack weighs 250 grams.

\subsection{Project Scope and Narrative Research Method}

The scope of the project is limited to UiTM Cawangan Selangor, Puncak Alam Campus. The 1,000-acre campus has twelve lakes. The campus population is about 23,000 students and staff.

Moving on, the methodology for the paper involved the combination of both the literature reviewed and the project processes which formed the narrative research design. According to Andrews, Squire, and Tamboukou (2013), narrative research is focused on the elicitation and interpretation of people's narrative accounts of their experience. The broader terms of narrative research consist of the qualitative data collection and the research design, while the narrower terms allow for life history research and personal narratives. Undertaking a narrative research project is a good fit as the narrative has acquired an increasingly high profile in social research (ibid). 
Reverting to the project paper methodology, Andrews et al. (2013) reiterated that unlike many qualitative frameworks, narrative research offers no automatic starting or finishing points. This is precisely what the campus sustainability project is all about. Also, narrative research offers no overall rules and suitable materials or modes of investigation (ibid). Consequently, the pekasam fish processes detailed above, together with the narrative research, formed the methodology for the project.

\subsection{Results of the Project}

Two hundred packets of pekasam fish at 250 grams per packet were produced from the first sustainable income generation initiative by UCS. Each packet was sold for RM15. As of the write-up of this paper, RM500 profit was obtained from the sale of the pekasam fish. The marketing and promotion of the product required the staff and students to assist as part of the social entrepreneurship skill set training. Through social media, the orders were accepted, and the product sold almost immediately.

The following illustrations show the processes applied to the campus sustainability initiative towards income generation. As depicted in Figure 1a, the students were seen scaling and removing the fish entrails. The process was demonstrated beforehand by the lecturer in charge, with two facilitators monitoring the students. In Figure $1 b$, the fishes were stacked after being rubbed with coarse salt.

Figure 2 a shows a bucket filled with fermented tilapias that are individually coated with roasted, grounded rice grains. The final product is the pekasam fish that has been vacuum packed (Fig. $2 b$ ).

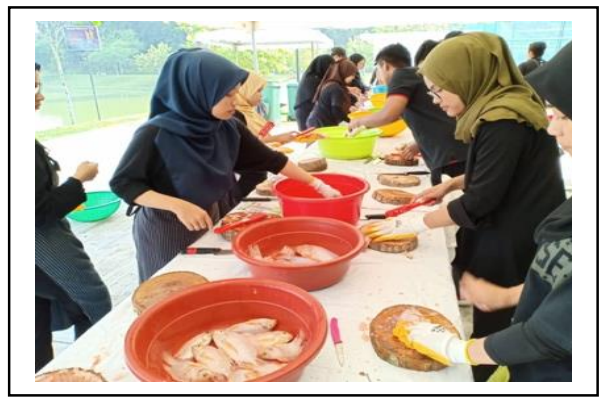

(a)

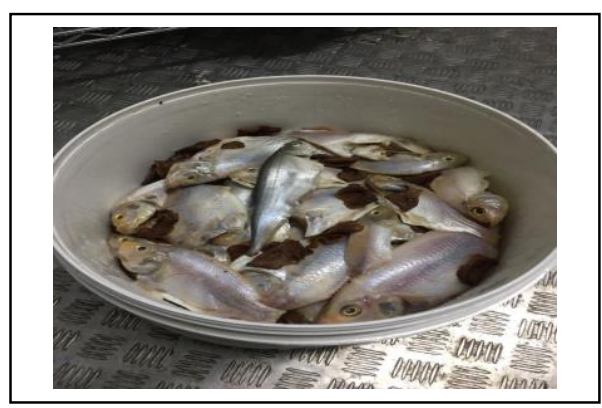

(b)

Fig. 1. (a) Cleaning fishes; (b) Fish rubbed with coarse salt for fermentation.

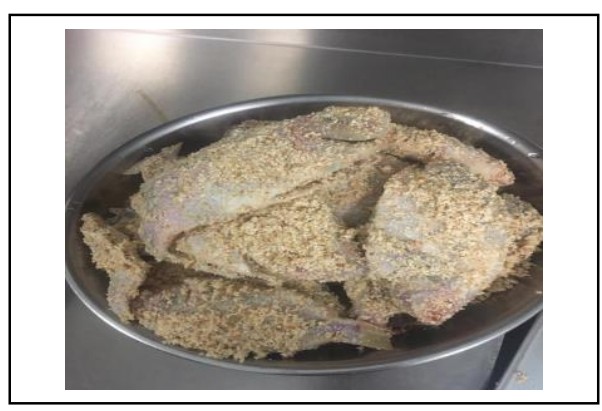

(a)

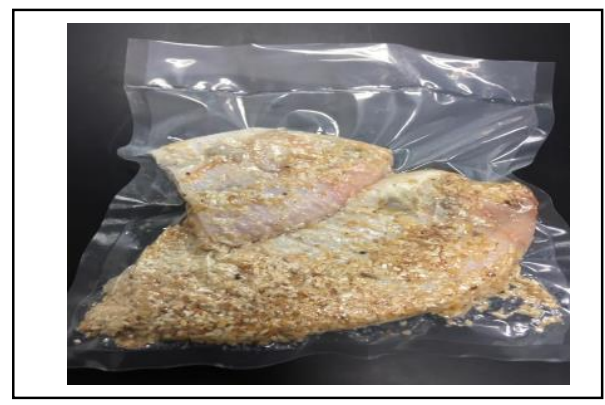

(b)

Fig. 2. (a) Fish coated with roasted, grounded rice; (b) vacuum-sealed fish pekasam.

\subsection{Limitations of Project}

The limitations of the project include a lack of empirical evidence. Although a survey was conducted, the empirical evidence does not fit the theme of this paper. That is, the survey was on a slightly different topic. Another limitation is the narrative aspect of the article, where the observations and practices of those involved were described, where elements of reliability and validity were not conducted.

\subsection{Conclusion and Recommendations}

In conclusion, campus sustainability and income generation by the university students and staff is of great importance towards organizational change and happiness at the workplace. Campuses with an abundance of biodiversity resources should use them for research and innovation opportunities. Any grounds for commercialization of natural, organic sources should be converted to income generation. In between, students should also be included for tacit skills training in social entrepreneurship. More importantly, sustainability research should also be systematically integrated into the teachings and 
institutional operations. Through these elements of entrepreneurship factors, immediate benefits, and economic sustainability will be recognized.

As for the recommendations for further study, it is advocated that a quantitative approach be undertaken to provide statistical evidence on project satisfaction among the students and staff. Also, the social change on the scope of the study would further provide holistic findings on the actual impact of the projects.

\section{Acknowledgments}

We would like to thank the Executive Management and the Tun Abdul Razak Library (PTAR) of Universiti Teknologi MARA, Selangor Branch (UCS), Puncak Alam Campus for the study scope and literature sources of the subscribed online databases. We would also like to thank the staff from the Facilities Department, UCS, who provided the campus's topology and landscape blueprints and the staff of the campus police, the health center, and student volunteers who participated in the project.

\section{References}

Andrews, M., Squire, C., \& Tamboukou, M. (2013). Doing Narrative Research (2nd ed.). London: SAGE Publications.

Brinkhurst, M. (2011). Achieving campus sustainability: top-down, bottom-up, or neither? International Journal of Sustainability in Higher Education, 12(4), 338-354. doi:10.1108/14676371111168269

Daub, C. H., Hasler, M., Verkuil, A. H., \& Milow, U. (2020). Universities talk, students walk: promoting innovative sustainability projects. International Journal of Sustainability in Higher Education, 21(1), 97-111. doi:10.1108/IJSHE-04-2019-0149

Ezzat, M. A., Zare, D., Karim, R., \& Ghazali, H. M. (2015). Trans- and cis-urocanic acid, biogenic amine and amino acid contents in ikan pekasam (fermented fish) produced from Javanese carp (Puntius gonionotus) and black tilapia (Oreochromis mossambicus). Food Chemistry, 172, 893-899. doi:10.1016/j.foodchem.2014.09.158

Ilham, J. I. J., Zaihan, M. H., Hakimi, S. M., Ibrahim, M. H., \& Shahrul, S. (2020) Mobilising the Sustainable Development Goals Through Universities: Case Studies of Sustainable Campuses in Malaysia. In. World Sustainability Series (pp. 121-133).

Mahyudin, N. A., Ibadullah, W. Z. W., \& Saadin, A. (2015). Effects of protein content in selected fish towards the production of lactic acid bacteria (Lactobacillus spp.) during the production of Pekasam. Current Research in Nutrition and Food Science, 3(3), 219-223. doi:10.12944/CRNFSJ.3.3.05

Martin, R. L., \& Osberg, S. (2007). Social entrepreneurship: The case for definition [article]. Stanford Social Innovation Review. Retrieved from $\mathrm{https}$ ://ssir.org/articles/entry/social_entrepreneurship_the_case_for_definition\#

Mcmillin, J., \& Dyball, R. (2009). Developing a Whole-of-University Approach to Educating for Sustainability:Linking Curriculum, Research and Sustainable Campus Operations. Journal of Education for Sustainable Development, 3(1), 55-64. doi:10.1177/097340820900300113

Muryany, I., Lian, H. H., Ina, S., Ghazali, A. R., Zamri-Saad, M., \& Rajab, N. F. (2018). Adhesion ability and cytotoxic evaluation of lactobacillus strains isolated from Malaysian fermented fish (pekasam) on Ht-29 and Ccd-18Co intestinal cells. Sains Malaysiana, 47(10), 2391-2399. doi:10.17576/jsm-2018-4710-15

Zaman, N. B. K., Lin, N. K., \& Phing, P. L. (2018). Chitosan film incorporated with Garcinia atroviridis for the packaging of Indian mackerel (Rastrelliger kanagurta). Ciencia E Agrotecnologia, 42(6), 666-675. doi:10.1590/1413-70542018426019918 